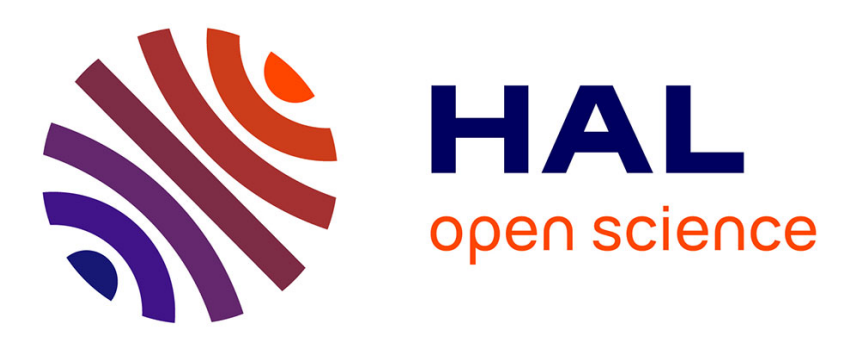

\title{
Sovereign bond spread drivers in the EU market in the aftermath of the global financial crisis
}

\author{
Iuliana Matei, Angela Cheptea
}

\section{To cite this version:}

Iuliana Matei, Angela Cheptea. Sovereign bond spread drivers in the EU market in the aftermath of the global financial crisis. 2013. hal-00845660

\section{HAL Id: hal-00845660 \\ https://hal.science/hal-00845660}

Preprint submitted on 17 Jul 2013

HAL is a multi-disciplinary open access archive for the deposit and dissemination of scientific research documents, whether they are published or not. The documents may come from teaching and research institutions in France or abroad, or from public or private research centers.
L'archive ouverte pluridisciplinaire HAL, est destinée au dépôt et à la diffusion de documents scientifiques de niveau recherche, publiés ou non, émanant des établissements d'enseignement et de recherche français ou étrangers, des laboratoires publics ou privés. 


\title{
Sovereign bond spread drivers in the EU market in the aftermath of the global financial crisis
}

\author{
Iuliana Matei $^{1}$ and Angela Cheptea ${ }^{2}$
}

Abstract: Recently the world economy was confronted to the worst financial crisis since the great depression. This unprecedented crisis started in mid-2007 had a huge impact on the European government bond market. But, what are the main drivers of this "perfect storm" that since 2009 affects EU government bond market as well? To answer this question, we propose an empirical study of the determinants of the sovereign bond spreads of EU countries with respect to Germany during the period 2003-2010. Technically, we address two main questions. First, we ask what share of the change in sovereign bond spreads is explained by changes in the fundamentals, liquidity and market risks. Second, we distinguish between EU member states within and outside the Euro area and question whether long-term determinants of spreads affect EU members uniformly. To these ends, we employ panel data techniques in a regression model where spreads to Germany (with virtually no default risk) are explained by set of traditional variables and a number of policy variables. Results reveal that large fiscal deficits and public debt as well as political risks and to a lesser extent the liquidity are likely to put substantial upward pressures on sovereign bond yields in many advanced European economies.

Key-words: Debt, Euro zone crisis, financial contagion, panel models.

JEL Classification: F33, E42, G15.

\footnotetext{
${ }^{1}$ Research Affiliate - CES Université Paris 1, 106 - 112 boulevard de L'Hôpital 75647 Paris cedex 13. Email : $\underline{\text { iuliana.matei@malix.univ-paris1.fr }}$

${ }^{2}$ Researcher-SMART, INRA, 4 allée Adolphe Bobierre - CS 61103, 35011 Rennes Cedex - Email: angela.cheptea@rennes.inra.fr
} 


\section{Introduction}

The last three years the world economy faced the worst financial crisis since the great depression. Started in mid-2007, this unprecedented crisis had huge impacts on the Euro zone government bond market. A mix of deteriorating economic prospects, failing commodity prices, growing risk aversion and huge financial stress have raised the concerns about the risk of a sharp increases of fiscal deficits and government debt in many countries. In the early 2009, market interest rates on sovereign debt have started to spike upward across a number of EU countries and have affected initially countries with large and vulnerable banking sectors. Accordingly, the rising share of sovereign bond flows in total capital inflows, especially in times of crisis, has become an issue of deep concern for many countries around the world.

With respect to the recent crisis, while the sovereign debt increases have been most pronounced only in a few euro area countries, they have become a real problem for the area as a whole. An increase in the gap between the yields of sovereign bonds issued by European Monetary Union (EMU) countries and the yields of bonds with similar characteristics issued by the German economy, assumed as virtually free of default risk, generates a similar shift in the market perceptions of the default risk in non EMUeconomies as well. Hence, spreads on the yields of European bonds reflect the premiums required by investors to hold these securities and are a component of the costs that countries have to pay when borrowing on external markets. If one combines this with the foreign currency risk faced by EU countries outside the euro zone, one adds to the potential threat.

Given the economic importance of yield spreads, it is not surprising that there is a large literature focusing on the determinants of yield spreads. A central issue closely investigated by this literature is how the market assesses sovereign default risk. This question has been addressed essentially for emerging countries: e.g. Edwards (1984), Cline and Barnes (1997), Kamin and Kleist (1999), Mody (2009), Jahjah and Zhanwei Yue (2010), Bellas, Papaioannou, and Petrova (2010). Although the evidence presented in these studies clearly suggests some empirical regularities for emerging markets, the debate about the "real" empirical model on driving forces of spreads is far from being settled. 
More, recently, an increasing number of papers focus on the determinants of the spreads on sovereign bond yields in the euro area: e.g. Cordogno et al. (2003), and Bernoth et al. (2006), Manganelli and Wolswijk (2009), Barbosa and Costa (2010), Oliveira et al. (2011) and Maltritz (2011). Results revealed by this strand of literature differ not only across time periods and country panels, but also for similar periods due to the use of different variables or methodologies. Studies on EU government bond yields can be divided into two broad categories: studies analyzing the period preceding and following the recent financial crisis, and studies concerned with creation of the European single currency and monetary union. Our paper contributes to the first type of literature. Furthermore, investigating yield spreads determinants at the level of the European Union is also relevant for an issue that has not been addressed so far in the literature. Our paper aims to fill-in these two gaps

Our contribution to this existing literature is fourfold. First, we consider a much larger country panel than previous studies. Existing works employ panel data techniques on (very) small data samples (up to 15 countries), which limits the validity of obtained results. Differently, we investigate the key drivers of yield spreads on government bonds issued by 25 EU countries. In line with the literature, we consider bonds issued by Germany to be free of risk and compute spreads as the difference between each country's interest rate and German interest rate. Our analysis carries on a eight year period (from 2003 to 2010), with special emphasis on years corresponding to the crisis period (2008-2010). Second, we distinguish between euro area members and other EU countries to explore the differences between the two groups and to test the robustness of our results across different panels of countries. Previous works ignore the role of exchange rate-risks in explaining yield spreads. The use of a panel combining both EMU and non EMU countries allows us to address the role of exchange rate policy in the assessment of sovereign default risk. Third, apart from factors identified in the literature, we test the presence of new driving forces of EU spread as political instability. More precisely, we estimate an empirical model in which spreads to Germany are explained by a set of explanatory variables including traditional determinants of spreads, such as GDP growth, inflation, debt, liquidity and other fiscal measures, as well as new sources of risk, namely the exchange rate regime, the political risk perception, and the financial crisis. We apply panel data estimation techniques and test the difference in impacts for EMU and non EMU countries, before and during the crisis. We test several hypotheses regarding the driving forces of EU spreads. This strategy is 
justified by the fact that there is no consensus about "an appropriate model" regarding the relevant drivers of yield spreads. Each work in the literature uses a different set of explanatory variables. In accordance to the panel structure of our data, we employ a fixed-effects model to estimate our results.

Our results suggest that large fiscal deficits, public debt, political risks, and, to a lesser extent, liquidity risks are likely to put substantial upward pressures on sovereign bond yields in many advanced European economies. Thus, our analysis reveals ways for national and regional governments to ease/avoid financial stress.

The reminder of the paper is as follows. Section 2 presents a brief review of the existing literature on the determinants of interest rate spreads on EU sovereign bonds. In section 3, we identify the main determinants of EU yield differentials, discuss their expected influence on the yield spreads and formulate the hypothesis that will be tested. Section 4 describes the empirical specification and presents our data sources. Results from the econometric estimations are reported in section 5. Section 6 concludes.

\section{Related literature}

This section reviews the existing literature on EU government bond yields or their spreads against a benchmark country (most often Germany).

Recent studies on EU government bond yields can be divided into two broad categories, studies analyzing the period preceding and following the recent financial crisis, and studies concerned with creation of the European single currency and monetary union. Both strands of this literature investigate the determinants of government bond yield spreads in the absence of exchange rate-risk in the Euro area since the creation of EMU.

Three drivers of yield spreads are found in all recent papers in the field: credit risk, liquidity indicators and changes in general risk aversion or international risk factor. Although the global financial crisis revealed all these types of risk, existing research, starting with Codogno et al. (2003) and Bernoth et al. (2004) and including more recent studies such as Manganelli and Wolswijk (2009), Haugh et al. (2009), Schuknecht et al. (2009), Barrios et al. (2010), Von Hagen et al. (2011), Pozzi and Wolswijk (2011), 
Maltritz (2011), Tavlas et al. (2011) and Oliveira et al. (2011) highlight the difficulty to distinguish between these interpretations of yield spreads.

The existing literature reports three types of credit risks: (1) the default risk, (2) the credit spread risk and (3) the downgrades risk. The default risk refers to the probability that the issuer fails to meet its financial obligations; the credit spread risk reflects the situation in which the bond market value does not exceed the value of other comparable quality bonds and the downgrades risk is the fear to being downgraded by a credit rating agency. This literature reveals a growing number of papers focusing on the role of credit risk traditionally captured by variables reflecting past or projections of future fiscal performance. Still, the findings on this component differ according to the considered period. Studies prior to the financial crisis (e.g., Codogno et al., 2003 and Bernoth et al., 2004), find evidence for credit risk as a major driving force of yield spreads. More precisely, Cordogno et al. (2003) explore the role of international risk in explaining yield spreads for nine EU countries from 1999 to 2002 period. They relate US corporate bond spread, US swap spreads to country-specific default risk factors, and find that the default risk, although relatively small, is a significant element of yield differentials, given its capacity to influence countries' fiscal discipline. Using data on EU Eurobonds issued between 1991 and 2002 (but ignoring the exchange rate risk), Bernoth et al. (2004) study the determinants of EU yield spreads against Germany and US and show that international risk factors (measured by US corporate risk) influence spreads while interactions of global risk with local fundamentals or liquidity indicators are less evident. In a different paper, (Bernoth et al., 2006), authors examine the effects of the monetary union on the risk premiums relative to Germany or US for 14 EU countries before and after the creation of the EMU. They find that the default risk premium is positively affected by debt and debt service ratios of the issuing country. Schuknecht et al. (2009) arrive to a similar conclusion, showing that the default risk is an essential component of yields spreads on a panel off 13 EU countries over the period 1991-2005.

The credit risk stands for a key driving force of yield spreads also in studies following the global financial crisis, too. Using time series cointegration techniques to analyze the determinants of Greek spreads relative to Germany from January 2000 to September 2010, Gibson et al. (2011) study the role of credit risk in explaining Greek spreads after the crisis erupted in 2009. They also present evidence on the share of risk premium 
unexplained by the credit rating of the Greek sovereign and point out that, despite the improvement in Greece's macroeconomic fundamentals in 2010, the widening of spreads was translated into a self-fulfilling crisis. Using panel data models, Schuknecht et al. (2010) highlight the role of credit risk in determining yield spreads for $15 \mathrm{EU}$ countries over the period 1991-2009. The fact that credit risk appears as a major component of EU yield spreads has been interpreted as evidence of the credibility of the Stability and Growth Pact, its goal being to enforce fiscal discipline among EMU members. However, findings of Manganelli and Wolswijk (2009) suggest that penalties imposed by financial markets were not sufficiently high to prevent fiscal imbalances in certain EU countries. They show that some ratings and short-term interest rates are pertinent spread drivers for 15 EU countries from 1991 to 2009.

Another key component of yield spreads is risk aversion (international risk factor), often associated with the willingness of investors to take risk. Haugh et al. (2009) point out the importance of the risk aversion in explaining yield spreads particularly in times of financial uncertainty as those known by euro zone since 2009. To assess the drivers of spreads for ten euro area countries, they apply a static panel model on quarterly spreads against Germany from 2005 to 2009. They identify the effects of fiscal policies on future deficits and the debt service ratio as relevant spread determinants. Looking at government bond yield spreads in the US and euro bond markets during two periods (pre-crisis and crisis periods - from 1991 to mid-2009), Von Hagen et al. (2011) study the role of risk aversion versus fiscal criteria to account for credit risk. Similarly to Haugh et al. (2009) and Barrios et al. (2010), they find evidence that fiscal imbalances are more penalized by markets since the 2008 Lehman Brothers' default. Manganelli and Wolwick (2009) find evidence in favor of a positive relation between international risk aversion, short-term interest rates and government bond spreads. They also point out the role of liquidity, and to a lesser extent of credit risks as factors of yield spreads on government bonds.

The role of liquidity in explaining government bond yield differentials across EMU members is somewhat contentious in the literature, especially on the pre-crisis period. The liquidity risk premium measures the extra interest rate an investor requires in compensation for bearing the risk of having to liquidate the security at a lower price than the benchmark. Studies as Codogno et al. (2003), Bernoth et al. (2004), Geyer and al. (2004) and Schuknecht et al. (2009) find evidence of a weak liquidity effect on EMU 
spreads, while Haugh et al. (2009), Beber et al. (2009) and Manganelli and Wolswijk (2009) show that liquidity is a strong driving force of spreads. By contrast, Favero et al. (2010) find that interaction between liquidity demand and risk is negative. A possible explanation of their finding is that econometric estimations take into account not only the dimension of country-specific risk, but also that of aggregate risk factors. The other three papers, do not pay attention to the last group. Oliveira et al. (2011) arrive at a similar conclusion as Favero et al. (2010) and find no evidence of a significant liquidity effect before or during the 2007 financial crisis period for seven EMU-countries during the 2000-2010 period and three yield maturities - 5, 10 and 15 year maturity.

As a final point, there is a common consensus in the literature that not only the fiscal discrepancies but also other macroeconomic imbalances have been strongly penalized by financial markets during the global financial crisis. Macro-fundamentals (e.g., trade balance, degree of openness and terms of trade), international risk conditions (e.g., US interest rates) or market sentiments (e.g., corporate bond spreads) and fiscal conditions are relevant drivers of yield spreads for Maltritz (2011). These results are obtained by applying a Bayesian approach to annual panel data from 1990 to 2009 in order to study the determinants of sovereign yield spreads of EMU member states. Using state space methods for weekly data over the period 1995-2009, Pozzi and Wolswijk (2011) look at the bond risk premium and the financial integration of government bond markets for five EMU countries: Belgium, France, Italy, Germany and the Netherlands. Their findings show that idiosyncratic factors were eliminated by 2006 in all countries, except for Italy since the beginning of the recent financial crisis and also that country-specific exposures to common international risk factors converged over the whole period across countries. The role played by the macroeconomic variables in the spreads dynamics has been revealed by other studies as well - see, for instance, Ang and Piazzesi (2003) and Lemke (2008), Mesonnier et al. (2011), Gärtner and Griesbach (2012).

Based on this succinct overview of the literature and on the theoretical arguments of benefits and costs of monetary unions, the next section identifies key drivers of EU yield differentials, discusses their expected influence on yield spreads and formulates some hypothesis. 


\section{Determinants of EU yield differentials and hypothesis}

Understanding what fundamentally drives the developments in EU yield spreads and why the driving forces of sovereign bond spreads could be different in EMU and nonEMU countries is an issue of interest to policymakers and practitioners alike.

The academic literature on government bond yield is consensual in establishing three main forces that drives the yield differentials: the credit risk, the liquidity risk and the investor's risk aversion. Given this finding, theoretical explanations on EU government bond differentials should be revolved around the theoretical arguments of benefits and costs of currency unification, financial integration and market discipline as well.

The adoption of the euro conferred several benefits on EMU members. First, there is a consensus in the literature that high inflation and inflation variability raise costs on the economy creating uncertainty and an inefficient allocation of resources. Higher price differentials lead to losses in competitiveness, to difficulties with debt service mainly for countries that lack an independent monetary policy (e.g., for pegged currencies or even common currencies), increasing the default risks. Dealing with inflation is not an easy think for EMU countries as they have to achieve the optimal inflation criterion of the Maastricht Treaty without an independent monetary policy. Furthermore, countries troubled in the past by episodes characterized by high inflation rates achieve easier low inflation rates by integrating a monetary union. Hence, the quality of euro area member guaranties low inflation rates which should be a major benefit mainly for EU countries with regular histories of high inflation. The first hypothesis to be tested will be the next:

H1: Higher inflation rates are associated with higher default risks, and accordingly with higher government bond spreads.

Furthermore, low inflation rates - underpinning by European Central Bank's monetary policy - are associated with reduced nominal interest rate which encourage borrowing and lending at longer maturities and therefore stimulates investment and growth and reduces yield spreads. Monetary policy can substantially affect the incentives to take risk via the interest rate. In this sense, Manganelli and Wolswijk (2009) report two main channels showing the link between investor's risk aversion and short term interest rate. First, low interest rates rise funding liquidity and the incentives of investment managers 
to take risk to boost the return on their investments. If interest rates are high investors are interested in safer assets while if interest rates are low, investors assume growing risks to maximize the return on their investments. Second, interest rates affect the state of the economy, which in turn is known to be related to agents' risk aversion. We formulate the second hypothesis:

H2: Lower interest rates are related with lower degrees of risk aversion, and therefore with lower government bond spreads.

Another important dimension often revealed by the existing literature and designed as stability criterion in the Maastricht Treaty is the government debt and deficit. The debt situation describes the payment obligations that governments have to perform. Higher government indebtedness increases the default risk and therefore yield spreads. This implies that the country has to spend additional money for debt service increasing the default probability of the country and accordingly, the credit risk.

H3: Higher levels of debt and of deficit raise the country default risks and therefore, the yield spreads.

The state of the economy is a key feature for a country desiring to fulfill easier the debt service requirements. The most important indicator used to capture this situation is the growth of GDP accepted to have a negative effect on spreads. Theoretical arguments around the sustainability of the country's debt (e.g., Domar, 1950) underline the relationship between the growth rate of GDP and the growth rate of debt pointing out that growing debt is not a problem as long as debt rises at a slower rate than the GDP. For EMU and non-EMU members of the European Union, we formulate the following hypothesis:

H4: Growing rates of GDP reduce ceteris peribus the country default risk.

Also, the introduction of the euro had several consequences on yield curves of euro zone countries. First, new euro-denominated debt was issued and simultaneously, all outstanding debt was redenominated in the new currency which involved the disappearance of currency risk premiums of inflation and devaluation. Therefore, the elimination of the exchange rate fluctuations and of the competitive devaluations among participating 
countries is a key benefit of joining the euro area. By contrast, non-EMU members are more exposed to exchange rate uncertainty and risk premiums, some of them experiencing in the past a chain of exchange rate crisis (e.g., Czech Republic, Hungary).

Taking into account the standardization of a large Euro-denominated bond market and the reduction of risk premium in "normal" times, recent literature highlights that market expectations should be that different public debt issues of the same maturity would become perfect substitutes. This interesting finding implies an increasing process of financial integration of the euro area financial markets with two main consequences: first, a diminishing liquidity effect on spreads involved by increasing "cross border trade securities"; second, a hamper effect on the market ability to discriminate the quality of EU fiscal policies; in this case, integrated financial markets do not allow a right appreciation from market participants among bonds issued by diverse governments. Most part of the studies considers that financial integration is a necessary condition for markets to work properly and exert their disciplinary effects (see, Manganelli and Wolswijk, 2009). It is important to highlight here that despite the increasing convergence process of yield on public debt in the pre-crisis period, the yield differentials against Germany do not disappear completely. Furthermore, during the recent financial crisis, spreads increased more because of the deterioration of some macroeconomic fundamentals.

Although euro area bond market has already achieved a high degree of integration, liquidity risk is still priced in by investors. In the case of non-EMU members, we expect a higher liquidity effect helping to explain some of the movements in yield spreads not accounted for by fiscal imbalance variables capturing the credit risk.

H5: Liquidity risk is higher for non-EMU members than EMU members

Finally, the countries' political stability may have an influence on yield differential. In this sense, market expectations are that governments destabilized or overthrown by unconstitutional means (including politically-motivated violence and terrorism) are not able to correctly fulfill their financial obligations which may increase interest rate costs and lead to higher market perception of default risk. The next hypothesis will be tested:

H6: Higher political instability lead to a substantial widening of yield spreads. 
The reduction in risk premia and in the nominal interest rates, the increase of GDP growth and political stability contribute to lower the costs of servicing the public sector debt facilitating fiscal adjustment and a more responsible allocation of the resources.

\section{Methodology and data}

This section deals with the empirical specifications which will be tested and with the data sources.

\subsection{The empirical specification}

The present paper examines the main drivers of European sovereign bond spreads to Germany in the aftermath of the recent global crisis. To this end, we consider the following equation:

$$
\operatorname{Spread}_{i t}=\mu+\beta \cdot H Y P_{i t}+\delta \cdot C V_{i t}+v_{i}+\varepsilon_{i t}
$$

where Spread $_{i t}$ is the difference between the yields of ten-year sovereign bonds issued by country $i$ in year $t$ and the yields of similar bonds issued by Germany. When spreads go up, market perceptions of the risks of default of these less developed EU economies go up too. Hence, the yields spreads measure the premium required by investors to hold such securities and they are a component of the costs that these less developed countries should pay when borrowing on the external markets. If one combines this with the foreign currency risk for EU countries that do not belong to the Euro Zone, one adds to the potential threat. HYP is the vector of our hypothesis variables: political stability, crisis and Euro Zone membership. $C V$ is a vector of control variables drawn from the recent empirical literature on long term spreads determinants: GDP growth, inflation, liquidity ratio, budget balance (surplus or deficit) and government debt. The term $v_{i}$ is the country-specific disturbance and $\varepsilon_{i t}$ is the disturbance component varying across both time and countries. To get the most out of the variation in the data and in line with the existing literature, we choose to log-linearize the variables. Some of our variables have a negative sign on the considered period which does not allow us for a simple logarithmic transformation. Instead, we employ the following transformation 
that permits to keep observations with negative-sign values for any variable $X$ taking both positive and negative values within the panel (Busse and Hefeker, 2007):

$$
Y=\ln \left(X+\sqrt{X^{2}+1}\right)
$$

There are two main approaches to analyze the determinants of sovereign yield spreads in the recent empirical literature, both with their pros and cons (Maltritz, 2011). The first one relates both dependent and independent variables to an "anchor" country (in this paper Germany) by taking the difference between observed values for each variable and its corresponding value for the anchor country. By doing so, this approach considers that the anchor country is not completely free of default risk. The second approach accepts the "free-risk" assumption regarding the benchmark country and consequently, explains the sovereign yield spreads with respect to the "anchor country" by the observed data for the selected explaining variables. The second approach implicitly assumes that the benchmark country is risk free or that its bond yield is the safest measure for a risk-less rate. We run the estimations by assuming the second approach where German bond yield is considered as the best approximation for a freerisk interest rate. This choice is reasonably motivated by recent movements in German yields that touched zero or a negative territory near to zero. The existing literature usually analyzes the first approach and checks the robustness of the estimations by applying the latter. We take the opposite way by considering the second approach that uses the observed data for the analyzed countries and the yield differentials against Germany.

The benchmark model becomes:

$$
\begin{aligned}
\ln _{\text {Spread }_{i t}=} & \alpha_{0}+\alpha_{1} \ln \text { GDPgrowth }_{i t}+\alpha_{2} \ln \text { Inflation }_{i t}+\alpha_{3} \ln \text { Debt }_{i t} \\
& +\alpha_{4} \ln \text { Liquidity }_{i t}+\alpha_{5} \ln \text { Deficit }_{i t}+\alpha_{6} \ln \text { Stability }_{i t}+v_{i} \\
& +\epsilon_{i t}
\end{aligned}
$$

where $\alpha_{1}$ to $\alpha_{6}$ are the estimated parameters. Furthermore, to test how EMU membership affects the impact of different variables on the bond yield spreads, we take an additional step and add interaction terms between explanatory variables and the Euro Zone dummy $E M U_{i t}$ : 


$$
\begin{aligned}
\ln _{\text {Spread }_{i t}=} & \alpha_{0}+\alpha_{1} \ln \text { GDPgrowt }_{i t}+\alpha_{2} \ln \text { Inflation }_{i t}+\alpha_{3} \ln \text { Debt }_{i t} \\
& +\alpha_{4} \ln \text { Liquidity }_{i t}+\alpha_{5} \ln \text { Balance }_{i t}+\alpha_{6} \ln \text { Stability }_{i t} \\
& +\beta_{1} \text { EMU }_{i t} \times \ln \text { Debt }_{i t}+\beta_{2} \text { EMU }_{i t} \times \ln \text { Liquidity }_{i t} \\
& +\beta_{3} \text { EMU }_{i t} \times \ln \text { Balance }_{i t}+v_{i}+\epsilon_{i t}
\end{aligned}
$$

Similarly, to test the impact of these variables during the 2008-2010 financial crisis, we add interaction terms with a crisis dummy which takes the value one for the last three years of our panel and zero elsewhere:

$$
\begin{aligned}
\ln _{\text {Spread }_{i t}=} & \alpha_{0}+\alpha_{1} \ln \text { GDPgrowt }_{i t}+\alpha_{2} \ln \text { Inflation }_{i t}+\alpha_{3} \ln \text { Debt }_{i t} \\
& +\alpha_{4} \ln \text { Liquidity }_{i t}+\alpha_{5} \ln \text { Balance }_{i t}+\alpha_{6} \ln \text { Stability }_{i t} \\
& +\gamma_{1} \text { Crisis }_{t} \times \ln \text { Debt }_{i t}+\gamma_{2} \text { Crisi }_{t} \times \ln \text { Liquidity }_{i t} \\
& +\gamma_{3} \text { Crisi }_{t} \times \ln \text { Balance }_{i t}+v_{i}+\epsilon_{i t}
\end{aligned}
$$

This is a convenient alternative to estimating equation (3) on the 2008-2010 sub-panel, as it does not induce a large drop in the number of observations, nor losses in terms of degrees of freedom.

\subsection{Data and variables}

The data panel contains observations from 25 EU countries and covers the 2003-2010 period. We included all countries for which the European Central Bank (ECB) publishes sovereign bond yields, i.e. all EU members except Estonia. Our panel does not include Germany since it is taken as reference. To study the main determinants of bond yield spreads, we take into account both time-series and cross-country variation in our data set. Our data are in annual frequency, meaning that the effects we identify below correspond to long term determinants of spreads.

Table 1 presents a brief summary of employed variables and data sources. Spreads on government bonds are computed as the difference between the yields on 10-year bonds issued by each country in our panel and Germany. We employ monthly data provided by the ECB and take annual averages. GDP growth and inflation are obtained from the Wolrd Bank's World Development Indicators (WDI) database. The liquidity ratio is computed as money and quasimoney (M2) divided by reserves exclusive of gold, both from the WDI database. Data on government debt and budget balance (deficit or 
surplus) come from the Eurostat. Finally, to assess countries' political stability we use the Political Stability and Absence of Violence/Terrorism ranking indicator from the World Bank's Worldwide Governance Indicators (WGI) database, computed by Kaufman, Kraay and Mastruzzi (2010). It measures the perceptions of the likelihood that the government will be destabilized or overthrown by unconstitutional or violent means, including politically-motivated violence and terrorism. It corresponds to the percentile rank among all countries and ranges from 0 (lowest) to 100 (highest) rank or political stability. (See http://info.worldbank.org/governance/wgi/index.asp for additional information.) This is an inverse measure of political insecurity and political risk. Unlike the spread, explanatory variables are expressed in levels rather than as differences with respect to Germany, which virtually is considered here as free of default risk.

Table 2 summarizes the labels and logarithmic transformations of variables used for estimating the model presented in section 2.1. As explained above, variables that take both positive and negative values need a more specific transformation. Table 3 exposes the main descriptive statistics of variables integrated in estimations.

Table 1: Data sources of explained and explanatory variables

\begin{tabular}{|c|c|c|}
\hline Variable & Explanation, computation & Data source \\
\hline Spread & $\begin{array}{l}\text { Difference between yields on 10-year } \\
\text { bonds of a given country and Germany, } \\
\text { annual average obtained from monthly } \\
\text { data }\end{array}$ & $\begin{array}{l}\text { European Central Bank (ECB) } \\
\text { statistics, monthly data }\end{array}$ \\
\hline GDP growth & Annual GDP growth (\%) & $\begin{array}{l}\text { World Development } \\
\text { (WDI), World Bank }\end{array}$ \\
\hline Inflation & $\begin{array}{l}\text { Annual inflation rate in terms of } \\
\text { consumer prices (\%) }\end{array}$ & $\begin{array}{l}\text { World Development Indicators } \\
\text { (WDI), World Bank }\end{array}$ \\
\hline Government debt & Total government debt as $\%$ of GDP & Eurostat \\
\hline Liquidity ratio & $\begin{array}{l}\text { Money (M2) to reserves (without gold) } \\
\text { ratio (\%) }\end{array}$ & $\begin{array}{l}\text { World Development Indicators } \\
\text { (WDI), World Bank }\end{array}$ \\
\hline Budget balance & $\begin{array}{l}\text { Public administration financing capacity } \\
(+) \text { or needs }(-) \text { as } \% \text { of GDP }\end{array}$ & Eurostat \\
\hline Political Stability & $\begin{array}{l}\text { The Political Stability and Absence of } \\
\text { Violence percentile rank of countries: the } \\
\text { higher the index, the lower the political } \\
\text { risk and the higher the stability }\end{array}$ & $\begin{array}{l}\text { Worldwide Governance Indicators } \\
\text { (WGI), World Bank }\end{array}$ \\
\hline
\end{tabular}


Table 2: Labels and transformations of explained and explanatory variables

\begin{tabular}{|c|c|c|}
\hline Variable & Variable label & Transformation \\
\hline Spread & Spread $_{i t}$ & $\ln \left(\right.$ Spread $\left._{i t}+\sqrt{\text { Spread }_{i t}^{2}+1}\right)$ \\
\hline GDP growth & GDPgrowth $_{i t}$ & $\ln \left(\right.$ GDPgrowth $_{i t}+\sqrt{\text { GDPgrowth }_{i t}{ }^{2}+1}$ \\
\hline Inflation & Inflation $_{i t}$ & $\ln \left(\right.$ Inflation $\left._{i t}+\sqrt{\text { Inflation }_{i t}^{2}+1}\right)$ \\
\hline Government debt & Debt $_{i t}$ & $\ln D e b t_{i t}$ \\
\hline Liquidity ratio & Liquidity $_{i t}$ & $\ln$ Liquidity $_{i t}$ \\
\hline Budget balance & Balance $_{i t}$ & $\ln \left(\right.$ Balance $\left._{i t}+\sqrt{\text { Balance }_{i t}^{2}+1}\right)$ \\
\hline Political Stability & Stability $_{i t}$ & $\ln$ Stability $_{i t}$ \\
\hline
\end{tabular}

Table 3: Descriptive statistics of explained and explanatory variables

\begin{tabular}{|c|c|c|c|c|c|c|c|c|c|c|}
\hline & 2003 & -2010 & & & & 2008 & $3-2010$ & & & \\
\hline Observed values & Obs. & Mean & $\begin{array}{l}\text { Std. } \\
\text { Dev. }\end{array}$ & Min & Max & Obs. & Mean & $\begin{array}{l}\text { Std. } \\
\text { Dev. }\end{array}$ & Min & Max \\
\hline Spread & 198 & 1.03 & 1.61 & -1.19 & 10.78 & 75 & 1.77 & 2.14 & -0.10 & 10.78 \\
\hline GDP growth & 200 & 2.32 & 4.16 & 17.95 & 12.23 & 75 & -0.74 & 4.57 & 17.95 & 9.43 \\
\hline Inflation & 200 & 3.01 & 2.58 & -4.48 & 15.40 & 75 & 2.85 & 2.92 & -4.48 & 15.40 \\
\hline Government debt & 200 & 50.80 & 27.65 & 6.10 & 144.90 & 75 & 56.01 & 29.57 & 13.40 & 144.90 \\
\hline Liquidity ratio & 198 & 103.16 & 243.69 & 1.32 & 2235.76 & 73 & 105.77 & 192.72 & 1.42 & 1025.38 \\
\hline Budget balance & 200 & -2.98 & 4.22 & 31.30 & 5.30 & 75 & -5.26 & 4.93 & 31.30 & 4.20 \\
\hline \multirow[t]{2}{*}{ Political Stability } & 200 & 73.92 & 15.98 & 34.12 & 100.00 & 75 & 73.06 & 16.47 & 34.12 & 100.00 \\
\hline & \multicolumn{5}{|c|}{$2003-2010$} & \multicolumn{5}{|c|}{$2008-2010$} \\
\hline $\begin{array}{l}\text { Logarithmic } \\
\text { transformations }\end{array}$ & Obs. & Mean & $\begin{array}{l}\text { Std. } \\
\text { Dev. }\end{array}$ & Min & Max & Obs. & Mean & $\begin{array}{l}\text { Std. } \\
\text { Dev. }\end{array}$ & Min & Max \\
\hline Spread & 198 & 0.66 & 0.72 & -1.01 & 3.07 & 75 & 1.04 & 0.76 & -0.10 & 3.07 \\
\hline GDP growth & 200 & 1.17 & 1.60 & -3.58 & 3.20 & 75 & -0.11 & 1.84 & -3.58 & 2.94 \\
\hline Inflation & 200 & 1.58 & 0.80 & -2.20 & 3.43 & 75 & 1.44 & 1.01 & -2.20 & 3.43 \\
\hline Government debt & 200 & 3.75 & 0.64 & 1.81 & 4.98 & 75 & 3.87 & 0.59 & 2.60 & 4.98 \\
\hline Liquidity ratio & 198 & 2.96 & 1.95 & 0.28 & 7.71 & 73 & 3.27 & 1.91 & 0.35 & 6.93 \\
\hline Budget balance & 200 & -1.24 & 1.50 & -4.14 & 2.37 & 75 & -1.94 & 1.29 & -4.14 & 2.14 \\
\hline Political Stability & 200 & 4.28 & 0.23 & 3.53 & 4.61 & 75 & 4.26 & 0.25 & 3.53 & 4.61 \\
\hline
\end{tabular}

Notes: Logarithmic transformations correspond to the last column on Table 2 
The GDP growth is an important determinant of the bond spread. It is usually used to capture the state of the economy and is supposed to have a negative influence on spread. Theoretical researches on the sustainability of the country's debt (e.g., Domar, 1950) highlight the relationship between the growth rate of GDP and the growth rate of debt pointing out that growing economies are more able to fulfill their financial obligations than the stagnating economies. Inflation influences economic activity but may also impact spreads. Higher price differentials lead to losses in competitiveness, mainly for countries that lack an independent monetary policy, such as pegged currencies, increasing the default risks. Furthermore, countries troubled in the past by episodes characterized by high inflation rates achieve easier low inflation rates by integrating a monetary union. The liquidity ratio measures the access to credit relative to national reserves According to the literature (e.g., Cartapanis, 2002), this ratio is also a good indicator for the capacity of the economies and central banks to face speculative attacks. Furthermore, a higher ratio can decrease investors' confidence in the economy and this could be a sign of a banking crisis followed by "flight to quality". The government debt is expected to have a positive influence on the spreads because higher levels of debt increase the default risk and as a consequence yield spreads. The fiscal performance of the economy is captured by the government's budget balance. Large fiscal deficits over a long period amplify the default risk and negatively affect spreads. The EMU dummy variable is used to capture not only the quality of the member of the monetary union, but also the exchange rate regime. Interaction terms between both debt, fiscal and liquidity variables on the one hand and the EMU dummy in the other hand are used to measure their amplified effect.

\section{Econometric results}

In this section we look at the determinants of spreads on sovereign bond yields of EU countries with respect to Germany over the entire 2003-2010 period and during the 2008-2010 crisis. The Hausman test statistics is always significant at the $1 \%$ level, pleading in favor of a fixed effects model. Results displayed in this section correspond to fixed-effects estimators. Table 1 displays correlation estimates for all variables considered in the empirical specifications (see the correlation matrix in the appendix). We observe that interaction terms are highly correlated with each other and also with dummy variables. Consequently, interaction terms will be added separately in the considered equations. 
Table 4 summarizes the effects of different determinants over the entire period. Column 1 shows parameter estimates of equation (3). The last three columns report the point estimates of equation (4) parameters with each EMU interaction term added separately in the equation. Indeed, the three interaction terms are highly correlated with each other and cannot be introduced simultaneously in the same estimation. In columns from (4) to (6), we present the estimates with membership and each EMU interaction terms introduced separately as well.

The state of the economy captured by the GDP growth has a negative and significant (at the $1 \%$ level) impact on sovereign bond yield spreads with respect to Germany. This finding is in line with theoretical literature predictions stating that growing economies are more able to respect payment obligations than stagnating countries. The inflation rate affects spreads positively but the effect is not statistically significant. High inflation rates reveal structural problems in government's finance reducing the real level of the accumulated debt. If investors anticipate high inflation they will demand high interest rates on government debt making public borrowing more expensive. Furthermore, in the case of countries without independent monetary policy (with pegged currencies or in a monetary union), which is the case of the most part of countries of our sample, price differentials may lead to losses in competitiveness which increases the default risk. Table 6 provides evidence for the situation in which inflation has positive effects mainly for EMU countries by including interaction terms between inflation and membership. The total government debt to GDP ratio raises significantly (at the $1 \%$ level) the spreads. The high absolute value of this effect confirms that debt level is an essential component of the risk premium incorporated in sovereign bond yields. The budget balance to GDP ratio has a negative and significant coefficient (at the $5 \%$ level) on spreads. A high surplus (or financing capacity) or a low deficit (or financing needs) depict a higher capacity of the country to honor payments on issued bonds and keeps the cost of sovereign debt (yields on new bonds) down, close to the of the free-risk reference. We also find that political stability reduces the cost differential on new bonds, although the effect is significant only at the $10 \%$ level. The effects of all these variables are in line with theoretical predictions and are robust across different specifications.

On the opposite, we do not find evidence of a negative effect of liquidity, as suggested by the theory. In all specifications but the last the liquidity ratio effect is not significantly different from zero. In column 6 , however, this ratio enters the equation with a positive 
and significant coefficient, revealing that an increase in liquidity of EMU countries has not been always positively appreciated by the market. One possible explanation is the fact that most EMU countries severely affected by the 2008-2010 crisis saw their liquidity ratio increase significantly in the years preceding the crisis ${ }^{1}$.

By including interaction terms between the EMU membership dummy and debt, liquidity and fiscal variables in columns 4 to 9 we are able to test whether the effects of these variables differ for EMU and non EMU countries, or as a country integrates the Euro Zone. We find a significant effect only for the budget balance. According to our findings, the government surplus or deficit is reflected only in the level of spreads of non EMU countries or prior to joining the EMU. The fact that the interaction term between the budget balance deficit and membership is positive and statistically significant (at 5\% and respectively, at $1 \%$ level) is not in line with theoretical predictions pointing out the membership's negative effects on the budget. One possible explanation is related to the market discipline view (see, Manganelli and Wolswijk, 2009). Accordingly, market participants may perceive the Stability and Growth Pact as not credible or inefficient, in which case Brussels 'decisions and recommendations concerning fiscal performances of EMU countries would have no impact on yield differentials. The opposite view is that the Stability and Growth Pact enjoys perfect credibility exerting correcting effects on the fiscal excess of national governments. However, the positive sign of the interaction term between budget balance deficit and membership may be related to the fact that public finances were not in sufficiently good shape after the financial crisis erupted in 2008 . Hence, it is difficult to make a distinction between these two contradictory views.

In Table 5 we test whether the effect of macroeconomic fundamentals change during the crisis. In the first two columns we restrict the sample to the crisis period, i.e. the last three years of our panel, and report estimates of our benchmark model given by equation (3). Accordingly, we end up with fewer observations and degrees of freedom for our estimation. Only three of the control variables included in the equation impact significantly the spread and all of them have the expected sign. Differently from results for the entire period, we find a larger positive effect for government debt and a negative effect for liquidity.

\footnotetext{
${ }^{1}$ The econometric estimations on the pre-crisis period for the non-EMU members show that coefficients for liquidity ratio are negative and statistically non-significant.
} 
Table 4: Determinants of sovereign bond yield spreads: 2003-2010

\begin{tabular}{|c|c|c|c|c|c|c|c|c|c|}
\hline & (1) & (2) & (3) & (4) & (5) & (6) & (7) & (8) & (9) \\
\hline GDP growth & $\begin{array}{c}-0.11^{* * *} \\
(0.02)\end{array}$ & $\begin{array}{c}-0.10^{* * *} \\
(0.02)\end{array}$ & $\begin{array}{c}-0.10^{* * *} \\
(0.02)\end{array}$ & $\begin{array}{c}-0.10^{* * *} \\
(0.02)\end{array}$ & $\begin{array}{c}-0.10^{* * *} \\
(0.02)\end{array}$ & $\begin{array}{c}-0.10^{* * *} \\
(0.02)\end{array}$ & $\begin{array}{c}-0.10^{* * *} \\
(0.02)\end{array}$ & $\begin{array}{c}-0.10^{* * *} \\
(0.02)\end{array}$ & $\begin{array}{c}-0.10^{* * *} \\
(0.02)\end{array}$ \\
\hline Inflation & $\begin{array}{c}0.02 \\
(0.04)\end{array}$ & $\begin{array}{c}0.02 \\
(0.04)\end{array}$ & $\begin{array}{c}0.02 \\
(0.04)\end{array}$ & $\begin{array}{c}0.03 \\
(0.04)\end{array}$ & $\begin{array}{c}0.01 \\
(0.04)\end{array}$ & $\begin{array}{l}-0.00 \\
(0.04)\end{array}$ & $\begin{array}{c}-0.02 \\
(0.04)\end{array}$ & $\begin{array}{c}0.01 \\
(0.04)\end{array}$ & $\begin{array}{c}0.00 \\
(0.04)\end{array}$ \\
\hline Government debt & $\begin{array}{c}0.80^{* * *} \\
(0.13)\end{array}$ & $\begin{array}{c}0.77^{* * *} \\
(0.13)\end{array}$ & $\begin{array}{c}0.77^{* * *} \\
(0.13)\end{array}$ & $\begin{array}{c}0.63^{* * *} \\
(0.14)\end{array}$ & $\begin{array}{c}0.78^{* * *} \\
(0.13)\end{array}$ & $\begin{array}{c}0.77^{* * *} \\
(0.13)\end{array}$ & $\begin{array}{c}0.77^{* * *} \\
(0.13)\end{array}$ & $\begin{array}{c}0.78^{* * *} \\
(0.13)\end{array}$ & $\begin{array}{c}0.77^{* * *} \\
(0.13)\end{array}$ \\
\hline Liquidity ratio & $\begin{array}{c}0.07 \\
(0.04)\end{array}$ & $\begin{array}{c}0.06 \\
(0.04)\end{array}$ & $\begin{array}{c}0.10 \\
(0.06)\end{array}$ & $\begin{array}{c}0.09 \\
(0.06)\end{array}$ & $\begin{array}{c}0.16 \\
(0.17)\end{array}$ & $\begin{array}{c}0.11^{*} \\
(0.06)\end{array}$ & $\begin{array}{c}0.07 \\
(0.06)\end{array}$ & $\begin{array}{c}0.18 \\
(0.15)\end{array}$ & $\begin{array}{c}0.11 \\
(0.05)\end{array}$ \\
\hline Budget balance & $\begin{array}{c}-0.07^{* *} \\
(0.03)\end{array}$ & $\begin{array}{c}-0.07^{* *} \\
(0.03)\end{array}$ & $\begin{array}{c}-0.07^{* *} \\
(0.03)\end{array}$ & $\begin{array}{l}-0.05^{*} \\
(0.03)\end{array}$ & $\begin{array}{c}-0.07^{* *} \\
(0.03)\end{array}$ & $\begin{array}{c}-0.13^{* * *} \\
(0.04)\end{array}$ & $\begin{array}{c}-0.07^{* *} \\
(0.03)\end{array}$ & $\begin{array}{c}-0.07^{* *} \\
(0.03)\end{array}$ & $\begin{array}{c}-0.13^{* * *} \\
(0.04)\end{array}$ \\
\hline Political Stability & & $\begin{array}{l}-0.54^{*} \\
(0.29)\end{array}$ & $\begin{array}{l}-0.53^{*} \\
(0.29)\end{array}$ & $\begin{array}{c}-0.53^{*} \\
(0.28)\end{array}$ & $\begin{array}{l}-0.54^{*} \\
(0.29)\end{array}$ & $\begin{array}{c}-0.61^{* *} \\
(0.28)\end{array}$ & $\begin{array}{l}-0.54^{*} \\
(0.29)\end{array}$ & $\begin{array}{l}-0.55^{*} \\
(0.29)\end{array}$ & $\begin{array}{c}-0.61^{* *} \\
(0.28)\end{array}$ \\
\hline EMU member & & & $\begin{array}{c}-0.17 \\
(0.21)\end{array}$ & $\begin{array}{c}-1.87^{* * *} \\
(0.74)\end{array}$ & $\begin{array}{c}-0.07 \\
(0.32)\end{array}$ & $\begin{array}{c}-0.01 \\
(0.22)\end{array}$ & & & \\
\hline EMU* Gov. debt & & & & $\begin{array}{l}0.45^{* *} \\
(0.19)\end{array}$ & & & $\begin{array}{c}-0.01 \\
(0.05)\end{array}$ & & \\
\hline EMU*Liquidity ratio & & & & & $\begin{array}{l}-0.07 \\
(0.17)\end{array}$ & & & $\begin{array}{c}-0.10 \\
(0.11)\end{array}$ & \\
\hline EMU*Budget.balance & & & & & & $\begin{array}{l}0.12^{* *} \\
(0.05)\end{array}$ & & & $\begin{array}{c}0.12^{* * *} \\
(0.05)\end{array}$ \\
\hline Constant term & $\begin{array}{c}-2.56^{* * *} \\
(0.54) \\
\end{array}$ & $\begin{array}{c}-0.10 \\
(1.40) \\
\end{array}$ & $\begin{array}{c}-1.82 \\
(1.41) \\
\end{array}$ & $\begin{array}{c}0.35 \\
(1.40) \\
\end{array}$ & $\begin{array}{c}-0.22 \\
(1.41) \\
\end{array}$ & $\begin{array}{c}0.07 \\
(1.39) \\
\end{array}$ & $\begin{array}{c}-0.12 \\
(1.41) \\
\end{array}$ & $\begin{array}{c}-0.23 \\
(1.41) \\
\end{array}$ & $\begin{array}{c}0.08 \\
(1.41) \\
\end{array}$ \\
\hline No. obs. & 196 & 196 & 196 & 196 & 196 & 196 & 196 & 196 & 196 \\
\hline $\mathrm{R}^{2}$ within & 0.541 & 0.551 & 0.553 & 0.568 & 0.553 & 0.568 & 0.551 & 0.553 & 0.568 \\
\hline $\mathrm{R}^{2}$ between & 0.052 & 0.018 & 0.019 & 0.005 & 0.024 & 0.017 & 0.018 & 0.026 & 0.017 \\
\hline $\operatorname{Corr}\left(u_{i}, X_{i t} \beta\right)$ & -0.684 & -0.662 & -0.658 & -0.691 & -0.674 & -0.662 & -0.661 & -0.682 & -0.662 \\
\hline$\rho=\sigma_{u}^{2} /\left(\sigma_{u}^{2}+\sigma_{e}^{2}\right)$ & 0.878 & 0.871 & 0.870 & 0.880 & 0.874 & 0.874 & 0.870 & 0.875 & 0.870 \\
\hline
\end{tabular}

Notes: The explained variable is expressed as change with respect to yields on German bonds. Fixed-effects estimators. Standard errors in parentheses. ${ }^{*} \mathrm{p}<0.10,{ }^{* *} \mathrm{p}<0.05,{ }^{* * *} \mathrm{p}<0.01$. 
Table 5: Determinants of sovereign bond yield spreads: 2003-2010

\begin{tabular}{|c|c|c|c|c|c|c|}
\hline & \multicolumn{3}{|c|}{$2008-2010$} & \multicolumn{3}{|c|}{$2003-2010$} \\
\hline & $(1)$ & $(2)$ & (3) & (4) & (5) & (6) \\
\hline GDP growth & $\begin{array}{l}-0.07^{* * *} \\
(0.03)\end{array}$ & $\begin{array}{l}-0.07^{* * *} \\
(0.03)\end{array}$ & $\begin{array}{l}-0.06^{* * *} \\
(0.02)\end{array}$ & $\begin{array}{l}-0.07^{* * *} \\
(0.02)\end{array}$ & $\begin{array}{c}-0.09 * * \\
(0.02)\end{array}$ & $\begin{array}{c}-0.08^{* *} \\
(0.02)\end{array}$ \\
\hline Inflation & $\begin{array}{c}0.06 \\
(0.06)\end{array}$ & $\begin{array}{c}0.06 \\
(0.06)\end{array}$ & $\begin{array}{l}-0.02 \\
(0.04)\end{array}$ & $\begin{array}{l}-0.01 \\
(0.04)\end{array}$ & $\begin{array}{c}0.01 \\
(0.04)\end{array}$ & $\begin{array}{c}0.02 \\
(0.04)\end{array}$ \\
\hline Government debt & $\begin{array}{l}1.00^{* * *} \\
(0.27)\end{array}$ & $\begin{array}{l}1.00^{* * *} \\
(0.27)\end{array}$ & $\begin{array}{l}0.65^{* * *} \\
(0.13)\end{array}$ & $\begin{array}{l}0.65^{* * *} \\
(0.13)\end{array}$ & $\begin{array}{l}0.71^{* * *} \\
(0.13)\end{array}$ & $\begin{array}{l}0.67^{* * *} \\
(0.13)\end{array}$ \\
\hline Liquidity ratio & $\begin{array}{l}-0.42^{* *} \\
(0.17)\end{array}$ & $\begin{array}{c}-0.39^{* *} \\
(0.17)\end{array}$ & $\begin{array}{l}-0.02 \\
(0.05)\end{array}$ & $\begin{array}{l}-0.01 \\
(0.05)\end{array}$ & $\begin{array}{c}0.03 \\
(0.05)\end{array}$ & $\begin{array}{c}0.02 \\
(0.05)\end{array}$ \\
\hline Budget balance & $\begin{array}{c}0.01 \\
(0.05)\end{array}$ & $\begin{array}{c}0.02 \\
(0.06)\end{array}$ & $\begin{array}{l}-0.03 \\
(0.03)\end{array}$ & $\begin{array}{l}-0.04 \\
(0.03)\end{array}$ & $\begin{array}{c}-0.06^{* * *} \\
(0.03)\end{array}$ & $\begin{array}{c}-0.02 \\
(0.03)\end{array}$ \\
\hline Political Stability & & $\begin{array}{l}-0.39 \\
(0.72)\end{array}$ & $\begin{array}{l}-0.69^{* * *} \\
(0.28)\end{array}$ & $\begin{array}{l}-0.63^{* * *} \\
(0.28)\end{array}$ & $\begin{array}{c}-0.54^{* *} \\
(0.28)\end{array}$ & $\begin{array}{c}-0.57^{* *} \\
(0.28)\end{array}$ \\
\hline Crisis & & $\begin{array}{l}0.29 * * * \\
(0.08)\end{array}$ & & & & \\
\hline Crisis* Gov. debt & & & $\begin{array}{l}0.07^{* * *} \\
(0.02)\end{array}$ & & & \\
\hline Crisis*Liquidity ratio & & & & $\begin{array}{c}0.03 \\
(0.02)\end{array}$ & & \\
\hline Crisis*Budget balance & & & & & $\begin{array}{l}-0.09 * * * \\
(0.03)\end{array}$ & \\
\hline Constant term & $\begin{array}{c}-1.54 \\
(1.28) \\
\end{array}$ & $\begin{array}{c}0.05 \\
(3.20) \\
\end{array}$ & $\begin{array}{c}1.17 \\
(1.39) \\
\end{array}$ & $\begin{array}{c}0.87 \\
(1.39) \\
\end{array}$ & $\begin{array}{c}0.19 \\
(1.41) \\
\end{array}$ & $\begin{array}{c}0.52 \\
(1.39) \\
\end{array}$ \\
\hline $\mathrm{N}$ & 73 & 73 & 196 & 196 & 196 & 196 \\
\hline $\mathrm{R}^{2}$ within & 0.520 & 0.524 & 0.588 & 0.581 & 0.557 & 0.570 \\
\hline $\mathrm{R}^{2}$ between & 0.176 & 0.198 & 0.026 & 0.000 & 0.009 & 0.000 \\
\hline $\operatorname{Corr}\left(u_{i}, X_{i t} \beta\right)$ & -0.544 & -0.520 & -0.480 & -0.511 & -0.604 & -0.538 \\
\hline$\rho=\sigma_{u}^{2} /\left(\sigma_{u}^{2}+\sigma_{e}^{2}\right)$ & 0.864 & 0.854 & 0.828 & 0.834 & 0.855 & 0.839 \\
\hline
\end{tabular}


This confirms the common belief that during a crisis markets follow closely the dependence of economies on debt. A one percent increase in the debt-to-GDP ratio results in an equal increase in spreads. During the crisis the liquidity ratio of most countries decreased, picturing a more constraint access to credit relative to national reserves. This increased the pressure on the credit market and pushed up the cost of newly issued bonds, countries with the largest drop in liquidity suffering the largest spread escalation.

Alternatively, we can test the effect of control variables during the crisis by adding the interaction between each variable and a crisis dummy on the left hand side of equation, producing equation (5). An important advantage of this approach is that estimations are performed on the entire panel. As previously, interaction terms are highly correlated with each other and, therefore, introduced one-by-one in the equation, Point estimates of parameters are displayed in columns 2 to 4 of Table 5. Again, we find that in times of crisis an economy's dependence on debt is more severely reflected in the spreads on the new sovereign bonds it issues.

Our results suggest that markets penalize governments with large budget deficits only during the crises, while the impact of liquidity is not statistically significantly different from zero. Estimates from the last three columns also confirm the role of a country's political stability in reducing the cost of its sovereign debt. This aspect is important since the political risk generally increases during a crisis. For example, the Economist Intelligence Unit argues that the level of threat posed to governments by social protests has increased in most European countries since 2007.

For robustness checks we have also computed the liquidity ratio as M2(money and quasimoney) over reserves including gold. Similarly, we used different measures of budget balance: the central administration [primary] budget balance and the public administration surplus or deficit, both computed as percentage of GDP. We obtained very similar results to those in Tables 4 and 5 for all specifications. In addition, we also estimate the model without making the risk-free assumption. For that both dependent and independent variables are related to the "anchor" country (Germany), i.e. all are expressed as deviations from values for Germany. Results confirm main previous findings, although some estimate points loose in significance, due to a lower variance in explanatory variables in this case. 
Table 6: Determinants of sovereign bond yield spreads: 2003-2010

\begin{tabular}{|c|c|c|c|c|c|}
\hline & (1) & (2) & (3) & (4) & (5) \\
\hline GDP growth & $\begin{array}{c}-0.06^{* * *} \\
(0.02)\end{array}$ & $\begin{array}{c}-0.06^{* * *} \\
(0.02)\end{array}$ & $\begin{array}{c}-0.07^{* * *} \\
(0.02)\end{array}$ & $\begin{array}{l}-0.11^{*} \\
(0.06)\end{array}$ & $\begin{array}{c}-0.06^{* * *} \\
(0.02)\end{array}$ \\
\hline Inflation & $\begin{array}{l}-0.02 \\
(0.04)\end{array}$ & $\begin{array}{l}0.03 \\
(0.04)\end{array}$ & $\begin{array}{l}-0.10^{*} \\
(0.06)\end{array}$ & $\begin{array}{l}0.11^{* * *} \\
(0.04)\end{array}$ & $\begin{array}{c}-0.02 \\
(0.04)\end{array}$ \\
\hline Gov. debt & $\begin{array}{l}0.65^{* * *} \\
(0.13)\end{array}$ & $\begin{array}{l}0.65^{* * *} \\
(0.13)\end{array}$ & $\begin{array}{l}0.67^{* * *} \\
(0.13)\end{array}$ & $\begin{array}{l}0.50^{* * *} \\
(0.13)\end{array}$ & $\begin{array}{l}0.65^{* * * *} \\
(0.13)\end{array}$ \\
\hline Liquidity ratio & $\begin{array}{c}0.03 \\
(0.06)\end{array}$ & $\begin{array}{c}0.11 \\
(0.14)\end{array}$ & $\begin{array}{c}0.01 \\
(0.05)\end{array}$ & $\begin{array}{c}0.03 \\
(0.06)\end{array}$ & $\begin{array}{c}0.04 \\
(0.06)\end{array}$ \\
\hline Budget balance & $\begin{array}{c}-0.03^{* *} \\
(0.03)\end{array}$ & $\begin{array}{l}-0.03 \\
(0.03)\end{array}$ & $\begin{array}{l}-0.04 \\
(0.03)\end{array}$ & $\begin{array}{l}-0.02 \\
(0.03)\end{array}$ & $\begin{array}{l}-0.03 \\
(0.03)\end{array}$ \\
\hline Political Stability & $\begin{array}{c}-0.67^{* *} \\
(0.28)\end{array}$ & $\begin{array}{c}-0.69^{* *} \\
(0.28)\end{array}$ & $\begin{array}{c}-0.65^{* *} \\
(0.28)\end{array}$ & $\begin{array}{c}-0.80^{* * *} \\
(0.27)\end{array}$ & $\begin{array}{l}-0.68^{* * *} \\
(0.28)\end{array}$ \\
\hline EMU member & $\begin{array}{l}-0.23 \\
(0.20)\end{array}$ & & $\begin{array}{l}-0.31 \\
(0.20)\end{array}$ & $\begin{array}{c}1.44 \\
(2.15)\end{array}$ & \\
\hline Crisis & $\begin{array}{l}0.29^{* * *} \\
(0.08)\end{array}$ & & $\begin{array}{l}0.29^{* * *} \\
(0.12)\end{array}$ & $\begin{array}{c}0.24 \\
(1.02)\end{array}$ & \\
\hline EMU* Gov. debt & & & & & \\
\hline EMU*Liquidity ratio & & $\begin{array}{l}-0.11 \\
(0.10)\end{array}$ & & & \\
\hline EMU*Budget balance & & & & & \\
\hline Crisis* Gov. debt & & & & & \\
\hline Crisis*Liquidity ratio & & & & & \\
\hline Crisis*Budget balance & & & & & \\
\hline EMU* Inflation & & & $\begin{array}{c}0.05 \\
(0.06)\end{array}$ & & \\
\hline Crisis* Inflation & & & $\begin{array}{c}-0.15^{* * *} \\
(0.04)\end{array}$ & & \\
\hline EMU* GDP growth & & & & $\begin{array}{l}-0.03 \\
(0.03)\end{array}$ & \\
\hline Crisis* GDP growth & & & & $\begin{array}{c}0.05 \\
(0.06)\end{array}$ & \\
\hline EMU* Political risk & & & & & $\begin{array}{l}-0.06 \\
(0.05)\end{array}$ \\
\hline Crisis* Political risk & & & & & $\begin{array}{l}0.07^{* * *} \\
(0.02)\end{array}$ \\
\hline Constant & $\begin{array}{c}1.09 \\
(1.39)\end{array}$ & $\begin{array}{c}1.04 \\
(1.39)\end{array}$ & $\begin{array}{c}1.03 \\
(1.39) \\
\end{array}$ & $\begin{array}{c}2.45^{*} \\
(1.42) \\
\end{array}$ & $\begin{array}{c}1.13 \\
(1.41)\end{array}$ \\
\hline $\mathrm{N}$ & 196 & 196 & 196 & 196 & 196 \\
\hline $\mathrm{R}^{2}$ within & 0.591 & 0.590 & 0.590 & 0.615 & 0.590 \\
\hline $\mathrm{R}^{2}$ between & 0.003 & 0.000 & 0.000 & 0.006 & 0.003 \\
\hline $\operatorname{Corr}\left(u_{i}, X_{i t} \beta\right)$ & -0.465 & -0.518 & 0.517 & -0.360 & -0.471 \\
\hline$\rho=\sigma_{u}^{2} /\left(\sigma_{u}^{2}+\sigma_{e}^{2}\right)$ & 0.825 & 0.840 & 0.840 & 0.811 & 0.826 \\
\hline
\end{tabular}

Notes: The explained variable is expressed as change with respect to yields on German bonds. Fixed-effects estimators. Standard errors in parentheses. ${ }^{*} \mathrm{p}<0.10,{ }^{* *} \mathrm{p}<0.05,{ }^{* * *} \mathrm{p}<0.01$. 
In table 6, we add interaction terms between the drivers of yield spreads identified above, and EMU membership and crisis variables. The first column shows parameter estimates of equation (3) augmented with a EMU membership and a crisis dummy. We find that a positive and significant impact on EU yield differentials for the crisis dummy, and a negative and statistically no significant effect for EMU membership. This result suggests that the recent financial crisis produced an important structural break in determining the evolutions of sovereign spreads. As previously, GDP growth, budget balance, government debt, and political stability are important drivers of differentials in EU bond yields. In a next step, we would like to add in a two separate estimations all interaction terms of these explanatory variables with the EMU dummy, and with the crisis dummy. We exclude terms which are highly correlated with other interaction terms or other left hand side variables (see the correlation matrix in the Appendix). Thus, in column 2 we keep only the interaction term between EMU membership and the liquidity ratio. All interaction terms with the crisis dummy are highly correlated with each other, which prevents us from running a similar equation to distinguish the impact of standard factors before and during the crisis.

We overcome this difficulty by including alternatively, for each of the above factors, the interaction terms with the EMU and the crisis dummies in the same specification. Estimation results are reported in the last three columns of the table. In columns 3 and 4 we test whether inflation and, respectively, GDP growth have larger positive effects for EMU member countries. We find a significant effect only for inflation. Although the coefficient of the interaction term between inflation and EMU membership is not statistically significant, its positive sign suggests that price differentials may lead to losses in competitiveness for EMU countries. Specifications 3 and 4 also show how the effect of inflation and GDP growth evolved with the crisis. We find that, during the global financial crisis, markets pay special attention to countries with high inflation rates. Estimates from the last column allow us to differentiate the role of political stability in decreasing the costs of a country's sovereign debt before and during the crisis, and the importance of this factor for EMU and non-EMU countries. Results are in line with the predictions of the Economist Inteligence Unit, highlighting that political risk increases during the crisis periods. 


\section{Conclusions}

This paper aims to identify the key drivers of sovereign bond spreads in EU countries from an ex-post perspective. Two main questions are addressed. First, we ask what proportion of the change in market spreads is explained by changes in the underlying fundamentals, external factors, liquidity and market risk. Second, we distinguish between Euro zone members and other EU countries and test how effects vary across the two groups.

To answer these questions we use a data panel of 25 EU countries from 2003 to 2010. We estimate an empirical model in which spreads to Germany on ten-year government bonds are explained by a set of variables including the exchange rate regimes, the political risk perception, and traditional determinants of spreads, such as GDP growth, inflation, debt, liquidity and fiscal measures. The data suggests the use of a fixed effect estimator. We find significant effects in line with theoretical predictions for all variables except inflation. The only difference in impacts between EMU and non EMU countries is obtained for the budget balance. According to our results, the government surplus or deficit is reflected only in the level of spreads of non EMU countries.

We also test the difference in the impacts of different explanatory variables before and during the 2008-2010 crisis. We conclude that during the crisis markets penalize more a high dependence on debt and larger drop in liquidity. As for large budget deficits, they are reflected in spread escalation only in times of crises. 


\section{Bibliography}

Ang, A. and M. Piazzesi, 2003. "A no-arbitrage vector autoregression of term structure dynamics with macroeconomic and latent variables“, Journal of Monetary Economics 50 (4), 745-787.

Barrios, S., Iversen, P., Lewandowska, M., Setzer, R., 2009, "Determinants of intra-Euro area government bond spreads during the financial crisis", European Economy, Economic Papers 388.

Barbosa L. and Costa S., 2010, "Determinants of sovereign bond yield spreads in the euro area in the context of the economic and financial crisis" Working Papers w201022, Banco de Portugal, Economics and Research Department.

Bellas D., Papaioannou M., G., and Petrova I., 2010, "Determinants of Emerging Market Sovereign Bond Spreads", IMF Working Paper 10/281.

Beber A., M. Brandt, and K. Kavajecz, 2009, "Flight-to-quality or flight-to-liquidity? Evidence from the euro-area bond market", Review of Financial Studies 22 (3), 925-957.

Bernoth, K., J. von Hagen, and L. Schuknecht, 2004, "Sovereign risk premia in the European government bond market", ECB working paper n³69.

Bernoth, K., J. von Hagen, and L. Schuknecht, 2006, "Sovereign risk premia in the European government bond market", University of Mannheim Paper.

Borgy V., T. Laubach, J.S. Mésonnier and J.P. Renne, 2012, "Fiscal sustainability, default risk and euro area sovereign bond spreads", Document de Travail, No.350 Banque de France.

Busse, M. and Hefeker C., 2007, "Political risk, institutions and foreign direct investment", European Journal of Political Economy, 23: 397-415.

Cartapanis A., 2002, "Les crises de change, qu'avons-nous appris depuis dix ans? “, Economie internationale, 88(4): 1-16

Cline, W., and K. Barnes, 1997, "Spreads and Risk in Emerging Market Lending," IIF Working Paper No. 97-1.

Cont, R., 2009, "Measuring systemic risk”, Working Paper, Columbia University.

Cont, R. and Moussa A., 2010, "Too interconnected to fail: default contagion and systemic risk in financial networks", mimeo.

Codogno, L., C. Favero and A. Missale, 2003, "Yield spreads on EMU government bonds", Economic Policy, October, pp. 503-532.

Edwards, S., 1984, "LDC Foreign Borrowing and Default Risk: An Empirical Investigation, 1976-80,” The American Economic Review, 74(4): 726-734.

Eichengreen, B., and A. Mody, 1998, "What Explains Changing Spreads on Emerging Market Debt: Fundamentals or Market Sentiment," NBER Working Paper No. 6408. 
Favero, Carlo, Marco Pagano, and Ernst-Ludwig von Thadden, 2010, "How does liquidity aaect government bond yields?", Journal of Financial and Quantitative Analysis 45 (1), 107-134.

Haugh, D., Ollivaud, P., Turner, D., 2009, "What drives sovereign risk premiums? An analysis of recent evidence from the Euro area", OECD Economics Department Working Papers No. 718.

Gärtner M., Griesbach B., 2012, "Have ratings been self-fulfilling during the European sovereign debt crisis?”, mimeo.

Geyer, A., Kossmeier, S., Pichler, S., 2004, “Measuring systematic risk in EMU government yield spreads", Review of Finance 8, 171-197.

Gibson H. D., S.G. Hall, G.S. Tavlas, 2011, “The Greek financial crisis: Growing imbalances and sovereign spreads", Journal of International Money and Finance, 2011, 1-19.

Jahjah S., Wei. B., V. Zhanwei Yue, 2010, “Exchange Rate Policy and Sovereign Bond Spreads in Developing Countries" IMF Working Paper 04/210.

Kamin, S. and Von Kleist K., 1999, "The Evolution and Determinants of Emerging Market Credit Spreads in the 1990s," BIS Working Paper 68.

Lemke, Wolfgang, 2008, "An affine macro-finance term structure model for the euro Area", North American Journal of Economics and Finance 19, 41-69.

Maltritz D., 2011, "Determinants of sovereign yield spreads in the Eurozone: A Bayesian approach", Journal of International Money and Finance, forthcoming.

Manganelli S. and G. Wolswijk, 2009, "What drives spreads in the euro area government bond market?", Economic Policy 24: 191-240.

Mody, A., 2009, "From Bear Stearns to Anglo Irish: How Euro zone Sovereign Spreads Related to Financial Sector Vulnerability", IMF Working Paper 09/108.

Oliveira, L., J. D. Curto and J.P. Nunes, 2011, "The determinants of sovereign credit spread changes in the euro-Zone", Journal of International Financial Markets, Institutions and Money, forthcoming.

Schuknecht, L., J. von Hagen and G. Wolswijk, 2009, "Government risk premiums in the bond market: EMU and Canada", European Journal of Political Economy, 25, 371-384.

Schuknecht, L., J. von Hagen and G. Wolswijk, 2010, “Government risk premiums in the EU revisited - the Impact of the Financial Crisis", ECB Working Paper Series No. 1152.

Von Hagen J., Schuknecht, L. and G. Wolswijk, 2011, “Government bond risk premiums in the EU revisited: The impact of the financial crisis", European Journal of Political Economy 27, 36-43.

Pozzi L. and G. Wolswijk, 2011, "The time-varying integration of euro area government bond markets", European Economic Review, doi: 10.1016/j.euroecorev.2011.05.006. 


\section{Appendix}

Table 1: Correlation matrix

\begin{tabular}{|c|c|c|c|c|c|c|c|c|c|c|}
\hline & $\begin{array}{l}\text { gdp } \\
\text { growth }\end{array}$ & debt gvnt & buget & liquid & polit stab & crisis & $\begin{array}{l}\text { emu*gdp } \\
\text { growth }\end{array}$ & $\begin{array}{c}\text { emu* } \\
\text { inflation }\end{array}$ & $\begin{array}{c}\text { emu*debt } \\
\text { gvnt }\end{array}$ & $\begin{array}{c}\text { emu*liqui } \\
\mathrm{d}\end{array}$ \\
\hline gdp_growth & 1 & & & & & & & & & \\
\hline debt_gvnt & -0.2948 & 1 & & & & & & & & \\
\hline buget & 0.3860 & -0.3986 & 1 & & & & & & & \\
\hline liquid & -0.1990 & 0.2475 & 0.0398 & 1 & & & & & & \\
\hline polit_stab & 0.0954 & -0.1458 & 0.2971 & 0.0463 & 1 & & & & & \\
\hline crisis & -0.6254 & 0.1482 & -0.3535 & 0.1231 & -0.0586 & 1 & & & & \\
\hline emu*gdp_growth & 0.5441 & -0.0576 & 0.3688 & 0.3168 & 0.1674 & -0.3590 & 1 & & & \\
\hline emu*inflation & 0.0586 & 0.2109 & 0.1428 & 0.6972 & 0.0388 & -0.0136 & 0.6009 & 1 & & \\
\hline emu*debt_gvnt & -0.2293 & 0.4967 & -0.0785 & 0.7756 & 0.0002 & 0.1477 & 0.3132 & 0.7620 & 1 & \\
\hline emu*liquid & -0.1840 & 0.2206 & 0.0257 & 0.9198 & 0.0578 & 0.1242 & 0.3600 & 0.7813 & 0.8914 & 1 \\
\hline crisis*debt_gvnt & -0.6297 & 0.2497 & -0.3864 & 0.1684 & -0.0774 & 0.9822 & -0.3689 & 0.0118 & 0.2105 & 0.1663 \\
\hline crisis*liquid & -0.5445 & 0.2589 & -0.2925 & 0.4501 & -0.0553 & 0.8072 & -0.3430 & 0.1868 & 0.4142 & 0.4277 \\
\hline crisis*budget & 0.6041 & -0.2560 & 0.6078 & -0.1028 & 0.2168 & -0.7629 & 0.3980 & 0.1161 & -0.1657 & -0.1164 \\
\hline emu*budget & 0.4036 & -0.5366 & 0.6358 & -0.3905 & 0.2157 & -0.3331 & 0.2497 & -0.2316 & -0.5820 & -0.4449 \\
\hline emu*inflation & 0.0586 & 0.2109 & 0.1428 & 0.6972 & 0.038 & -0.0136 & 0.6009 & 1.0000 & 0.7620 & 0.7813 \\
\hline crisis*inflation & -0.2901 & -0.0065 & -0.1621 & -0.0359 & -0.0990 & 0.7497 & -0.0775 & 0.1569 & -0.0320 & -0.0382 \\
\hline emu*pol_stab & -0.1812 & 0.3029 & 0.0452 & 0.8301 & 0.1503 & 0.1176 & 0.3955 & 0.7959 & 0.9597 & 0.9418 \\
\hline crisis*pol_stab & -0.6134 & 0.1412 & -0.3367 & 0.1218 & -0.0093 & 0.9972 & -0.3497 & -0.0124 & 0.1468 & 0.1239 \\
\hline emu*growth & 0.5441 & -0.0576 & 0.3688 & 0.3168 & 0.1674 & -0.3590 & 1.0000 & 0.6009 & 0.3132 & 0.3600 \\
\hline crisis*growth & 0.7246 & -0.0728 & 0.1651 & -0.0635 & 0.1321 & -0.0491 & 0.4761 & 0.1881 & -0.0462 & -0.0566 \\
\hline emu & -0.1924 & 0.3324 & 0.0221 & 0.8361 & 0.0851 & 0.1229 & 0.3823 & 0.8020 & 0.9722 & 0.9476 \\
\hline crisis & -0.6254 & 0.1482 & -0.3535 & 0.1231 & -0.0586 & 1.0000 & -0.3590 & -0.0136 & 0.1477 & 0.1242 \\
\hline
\end{tabular}




\begin{tabular}{|c|c|c|c|c|c|c|c|c|c|c|c|}
\hline & $\begin{array}{c}\text { crisis*deb } \\
\text { t gvnt }\end{array}$ & $\begin{array}{l}\text { crisis* } \\
\text { liquid }\end{array}$ & $\begin{array}{c}\text { crisis } \\
\text { budget }\end{array}$ & $\begin{array}{c}\text { emu } \\
\text { budget }\end{array}$ & $\begin{array}{c}\text { emu } \\
\text { inflation }\end{array}$ & $\begin{array}{c}\text { crisis } \\
\text { inflation }\end{array}$ & $\begin{array}{c}\text { emu } \\
\text { pol_stab }\end{array}$ & $\begin{array}{c}\text { crisis } \\
\text { pol_stab }\end{array}$ & $\begin{array}{l}\text { emu } \\
\text { growth }\end{array}$ & $\begin{array}{l}\text { crisis } \\
\text { growth }\end{array}$ & emu \\
\hline crisis_debt_gvnt & 1 & & & & & & & & & & \\
\hline crisis_liquid & 0.8401 & 1 & & & & & & & & & \\
\hline crisis_budget & -0.7977 & -0.6247 & 1 & & & & & & & & \\
\hline emu_budget & -0.4012 & -0.5070 & 0.4995 & 1 & & & & & & & \\
\hline emu_inflation & 0.0118 & 0.1868 & 0.1161 & -0.2316 & 1 & & & & & & \\
\hline crisis_inflation & 0.6965 & 0.4779 & -0.4448 & -0.0380 & 0.1569 & 1 & & & & & \\
\hline emu_pol_stab & 0.1612 & 0.3863 & -0.0961 & -0.4460 & 0.7959 & -0.0465 & 1 & & & & \\
\hline crisis_pol_stab & 0.9772 & 0.8041 & -0.7412 & -0.3215 & -0.0124 & 0.7414 & 0.1243 & 1 & & & \\
\hline emu_growth & -0.3689 & -0.3430 & 0.3980 & 0.2497 & 0.6009 & -0.0775 & 0.3955 & -0.3497 & 1 & & \\
\hline crisis_growth & -0.0705 & -0.0968 & 0.2201 & 0.1610 & 0.1881 & 0.2201 & -0.0239 & -0.0343 & 0.4761 & 1 & \\
\hline emu & 0.1703 & 0.3966 & -0.1131 & -0.4755 & 0.8020 & -0.0430 & 0.9964 & 0.1255 & 0.3823 & -0.0328 & 1 \\
\hline crisis & 0.9822 & 0.8072 & -0.7629 & -0.3331 & -0.0136 & 0.7497 & 0.1176 & 0.9972 & -0.3590 & -0.0491 & 0.1229 \\
\hline
\end{tabular}

